\title{
Effectiveness of Online Learning during the Covid-19 Pandemic on Economic Subjects in High Schools
}

\author{
Yuntafiani Mufidatu Rahmawati ${ }^{1}$, Lukman Hakim ${ }^{2}$, Tri Murwaningsih ${ }^{3}$ \\ \{yunta.fiani08@gmail.com ${ }^{1}$, lukkim@gmail.com ${ }^{2}$, murwaningsih_tri@yahoo.com ${ }^{3}$ \}
}

Magister of Economic Education, Sebelas Maret University, Surakarta, Indonesia ${ }^{1,2,3}$

\begin{abstract}
The Covid-19 pandemic has an impact on changing learning methods from faceto-face learning to online learning, learning activities that were originally carried out in schools because of the pandemic must be carried out at home. This learning method then made many teachers use various online learning media as an alternative learning which turned out to cause many complaints from students. The application of online learning due to changes in learning methods is a phenomenon that is studied more deeply by researchers using a descriptive qualitative approach. There are three kinds of data collection techniques used in this research, namely the observation method, the documentation method, and the interview method. All data obtained by the researcher were analyzed in detail, then the validity of the data was carried out using triangulation of techniques and techniques. The findings of this study indicate that the google classroom learning platform is preferred by teachers over other learning platforms such as Edmodo, WhatsApp Group, Zoom.us, and Google Meet. The Google Classroom learning platform is considered effective by teachers and easily accessible by students so that students can learn independently. Many learning features make it easier for teachers to create, modify, and monitor learning so that learning is more interesting, flexible, and a collection of student assignments can be known in more detail.
\end{abstract}

Keywords: Effectiveness, Alternative Learning, Online Learning.

\section{Introduction}

2020 will be a historic year for the development of human life. Since the outbreak of cases related to the corona virus that occurred in Wuhan, China at the end of 2019, this virus has become a trending topic around the world. Indonesia is one of the countries in the world that cannot be separated from the Covid-19 outbreak. The origin of the Covid-19 pandemic in Indonesia began with the discovery of a Corona Virus sufferer on March 2, 2020, then this virus was rampant throughout Indonesia. Various anticipations were made to break the chain of the spread of Covid-19, such as calls to the public to carry out social distancing (stay at home), lockdown efforts, government policies to carry out rapid tests and in several areas it has been enacted on a large scale. scale of social boundaries.

Efforts to prevent the Covid-19 pandemic continue to be carried out by all levels of society. The appeal to stay at home, make all community activities carried out at home such as working at home, studying at home, even praying at home. The spread of Covid-19 initially had a major impact on health and the economy, but the increasing spread of Covid-19 also has an impact on the education sector. The decision to carry out learning activities at home is a challenge in the world of education [1]. The existence of this decision caused a change in the way of learning which was initially face-to-face where students and teachers carried 
out the learning process at school, but due to the Covid-19 pandemic, the learning process had to be done at home online or online [2],[3]. Behaviorists believe that humans are greatly influenced by environmental conditions, so that they can provide certain experiences to themselves [4]. Such conditions require teachers to find ways that can be used to support the learning process so that students get the right to learn. Finally, as an alternative to learning to solve this problem, teachers use technology to support online learning.

The application of online learning is an alternative for implementing technologyassisted learning as a medium that can be used by teachers in providing learning to students effectively [4]. Teachers are expected to be able to become facilitators for students during the learning process, and to support them, teachers can use learning media that students can use to support the learning process in all conditions [5]. Basically online learning is a term of learning through media by utilizing electronic or digital [6]. The use of online learning media is a learning innovation that makes it easy for students, because online learning can help students transfer information to develop knowledge, skills and learning flexibility more efficiently [7].

Technology has an important role in the learning process, when applied inside and outside the classroom [8]. The application of online learning media aims to support the learning process, so that the information conveyed by the teacher during learning becomes better and easier for students to understand [9]. Students can freely use smartphones to access learning materials, so learning becomes more flexible. Online learning is an effective alternative to learning by combining the delivery of digital learning materials as support and services in the learning process using various existing learning platforms [10]. Teachers can use a learning platform that can make learning easier for students. Online learning platforms that are often used during the learning process include Google Classroom, Edmodo, zoom.in, webex and even google meet [11]. To be more optimal, using this learning platform can also be used by using communication media such as WhatsApp, telegram, messenger, and so on [9].

Based on the focus points studied by the researcher, this study examines alternative learning carried out by the Economic Subject Teacher Deliberation group, as many as 52 teachers who are members of the Economic MGMP group, there are 37 teachers who are over 40 years old, the rest are under 40 years. $80 \%$ of the total MGMP teachers explained that they prefer to use the google classroom learning platform, 50\% use video conferencing platforms such as zoom.us and google meet, and $4 \%$ use the edmoodo platform. As well as the majority of teachers who facilitate communication, prefer short message applications such as WhatsApp Group and Telegram.

This study examines more deeply the effectiveness of implementing learning during the Covid-19 pandemic in economic subjects including the challenges faced by teachers in choosing learning media as an alternative to learning in the face of the Covid-19 pandemic in economic subjects, alternative learning solutions in the face of the Covid pandemic. -19 on economic subjects and the effectiveness of the application of online learning as an alternative to learning during the Covid-19 pandemic in economic subjects. Changes in the learning process certainly have an effect on teacher performance [12], for young teachers there may be no problem if learning is done online using an online platform, but for teachers who lack technological skills because of Kudet (not updated) and age collide with difficulties in doing online learning.

Online learning is one solution that can be done during the Covid-19 pandemic, learning is much more flexible because it can be done at home [12]. However, this kind of learning creates new problems for students regarding their readiness to do online learning. Learning systems like this require high costs such as providing internet quota, procuring 
standard smartphones for online use, strong internet signal networks, and not to mention if there are questions that make it difficult for students.

Education observer Drs. Sulthon, M.Si, quoted from Gema Surya Fm, explained that online learning is actually a one-sided policy, without paying attention to student conditions related to facilities and financial conditions. The unavailability of quotas due to the small amount of money resulted in many students being in arrears for teacher assignments which over time became a lot and ultimately affected the learning process. Many students also cannot take part in learning because the internet signal network is experiencing interference. In addition, based on the explanation from the teacher, it is stated that online learning is an opportunity for stubborn students not to take part in learning for various supporting reasons. Of course, the problems that teachers and students complain about have a big impact on the effectiveness of the application of online learning.

The application of learning that is carried out online does not necessarily run smoothly, but creates new problems, namely related to the readiness of teachers and students to carry out the learning process using online learning platforms. For teachers who are young, maybe there will be no problems if the learning is done online, but for teachers whose technological skills are lacking due to inadequate updates and age clashes, they will definitely find it difficult to do online learning. Meanwhile, another complaint is that a learning system like this requires a fairly high cost for internet quota provision, standard smartphone procurement for online use, and not to mention if there are questions that make it difficult for students. Many students cannot participate in learning because the internet signal network is experiencing interference. In addition, based on the teacher's explanation, online learning is an opportunity for stubborn students not to take part in learning for various reasons. Therefore, researchers further analyzed the effectiveness of the application of online learning as an alternative to learning during the Covid-19 economic pandemic in high school.

\section{Research Methods}

Sugiyono explains that the research method is a scientific way to obtain data with specific purposes and uses [13]. This study uses a descriptive qualitative research approach. Descriptive qualitative research is a research based on the philosophy of postpositivism, to study natural objects the researcher is a key instrument, data collection techniques are carried out by means of triangulation (combined) [13]. Data grouping in this study is divided into two data, namely primary data and secondary data. Primary data sources in this study were obtained through interviews and observations. The primary data sources in this study were obtained from the teacher as the most important informant in the study. While secondary data is used by researchers as supporting information obtained from primary data sources, namely from literature studies, literature studies, previous research, books, or activity reports held by teachers on subjects. the economy.

There are three kinds of data collection techniques used in this research, namely the observation method, the documentation method, and the interview method. This study uses non-participatory observational research techniques, where the researcher is not directly involved in the activities of the observed informant, and only acts as an independent observer. Descriptive qualitative research requires researchers to be able to reveal objective truths related to the focus of the research they want to know, therefore the validity or validity of data in qualitative research is very important. The validity of this study used triangulation techniques. Triangulation can mean that there are different informants or different sources of 
data about something. Triangulation is done to strengthen the data, so that researchers believe in the truth and completeness of the data obtained.

Data analysis is inductive or qualitative and the results of the study emphasize meaning rather than generalization. This qualitative data analysis method uses data analysis techniques Miles and Huberman, where data analysis techniques are divided into data collection, data reduction, data presentation, and drawing conclusions / verification.

\section{Research Results and Discussion}

The following are the results of research on the Effectiveness of the Application of Online Learning as an Alternative to Learning in the Covid-19 Pandemic Period in Economics in High Schools.

\subsection{Implementation of learning during the Covid-19 pandemic in economic subjects in high schools}

The application of technology-based online learning is one form of implementing learning by utilizing technology as a medium for transferring knowledge from teachers to students. Indrajit explains that in the term e-learning, there is the word e- which basically represents an electronic word which means the occurrence of learning events using electronic-based devices [6]. Littlejhon and Pegler argue that e-learning is a teaching and learning process using computers and technology, especially learning using the internet [14]. The application of online learning media provides various benefits in the field of education, as explained by Lage-Cal \& Folgueras-Diaz [15]; Simuth \& Schuller which states that the advantages of e-learning emphasize flexibility during the learning process [16]. Students can learn more independently and more freely, students can be more responsible in learning so that the Student Center Learning (SCL) learning method can be achieved.

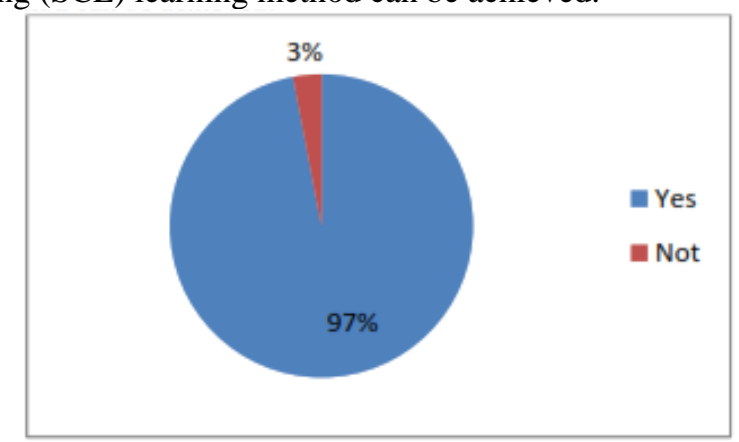

Fig 1. Application of online learning in economic subjects.

The decision regarding distance learning makes all subjects applied online, and economics is no exception. Based on the research data obtained by researchers, there were $97 \%$ of respondents who explained that learning was carried out online in all subjects including economics, and the remaining 3\% of respondents did not apply online learning. The implementation of this online learning is in accordance with the decision of the Minister of Education and Culture (Mendikbud) Nadiem Anwar Makarim with the approval of President Joko Widodo by issuing Circular Number 4 of 2020 concerning the Implementation of Education during the Covid-19 pandemic. 
Tigowati et al. explain that the purpose of online learning is to help conventional learning so that students can easily receive subject matter [17]. Therefore, a learning platform that is easily accessible by teachers and students is needed so that learning can run according to planning [18]. In accordance with research conducted by researchers, there are $75.9 \%$ of respondents using various online learning applications / facilities that can facilitate access in delivering learning to students, while $24.1 \%$ of respondents use online learning facilities that have been provided by schools, such as learning systems. e-learning that has been implemented in several schools. In fact, schools have provided flexibility to teachers in delivering material using a learning platform that is tailored to the needs of teachers and students in learning. One of the success factors in using online learning is the ease of access for students and teachers in using appropriate online tools.

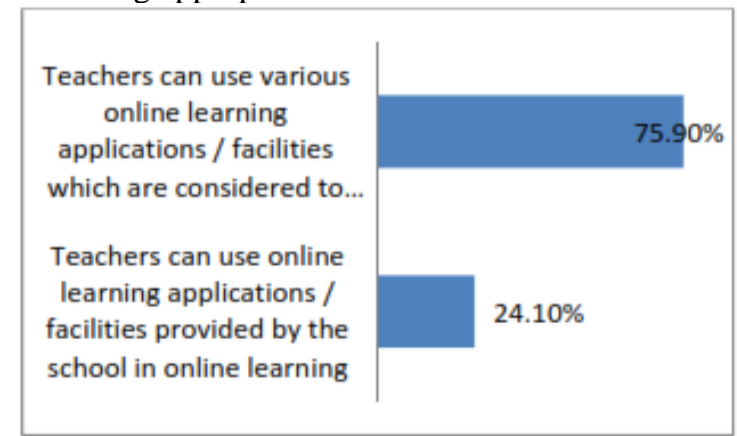

Fig. 2. Policy delivered by the school regarding the use of online learning applications / facilities

Online learning is carried out by all teachers including economics teachers using various online learning platforms. describes the platform is a combination of software and hardware to run a program. Its function is to make it easier for computer users to run applications smoothly.

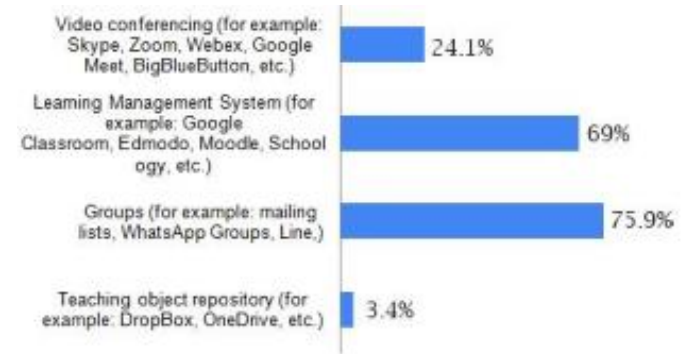

Fig. 3. Online learning media used in implementating economic learning

Based on data from the results of research conducted by researchers, there were $75.9 \%$ of responses that explained that teachers used mailing lists such as WhatsApp Group to communicate with students, and there were $69 \%$ of responses that explained that teachers prefer to carry out online learning based on google classroom. Furthermore, there were $24.1 \%$ of respondents who carried out online learning based on video conferencing in the form of zoom.us and google meet. Other supporting media so that learning can be maximized, namely teachers can easily communicate with students using Whatsapp. 


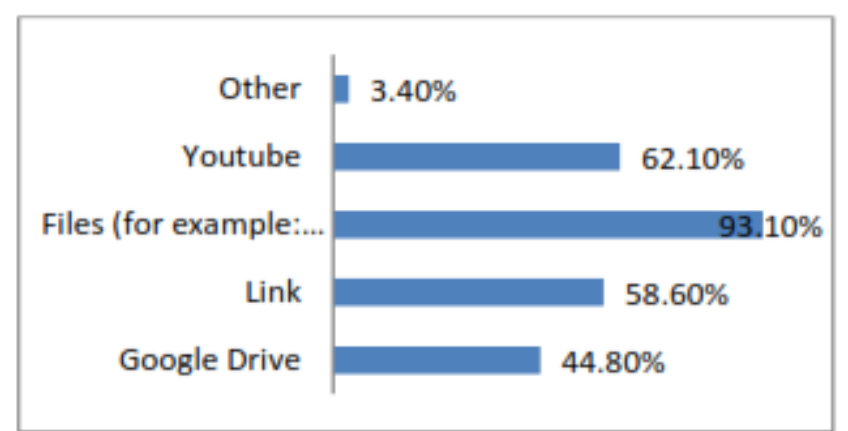

Fig. 4 Learning facilities use in delivering course material online learning

The application of online learning requires teachers to be more innovative in developing learning materials. $93.1 \%$ of respondents stated that teachers delivered subject matter in the form of files such as words, power points, even learning videos, $62.1 \%$ of teachers delivered learning materials using YouTube, 58.6\% of respondents delivered subject matter using links or links that could be accessed by students. And there are $44.8 \%$ of respondents who use Google Drive, and there are $3.4 \%$ of respondents who choose Google Form to deliver learning materials.

The delivery of assignments during online learning is quite diverse, ranging from making multiple choice questions, essay questions, true and false questions, summarizing, looking for articles to making mind mapping. The purpose of delivering this assignment is as an evaluation material to determine the ability of students to carry out online learning independently [16]. The form of essay questions is preferred by the teacher because it is intended to measure higher order thinking processes. So that the teacher is able to know the ability of students to express their opinions openly in accordance with the material presented by the teacher. For multiple choice questions selected by the teacher to measure low to moderate thinking processes, the difficulty level of the questions can also be controlled by the teacher. Multiple choice questions can help the teacher to score students more quickly and accurately because the correct answer for each item is clear and certain. In the process of submitting assignment results, students usually send the results of their assignments to the facilities available on the google classroom, or via mailing lists such as WhatsApp, email, google drive, or e-learning media provided by the school. Furthermore, the teacher will provide feedback to students regarding the results of student work.

\subsection{Constraints faced by the teacher when the learning pattern changes from face-to- face to online}

The application of online learning does help teachers in implementing learning effectively, but that does not mean it cannot be separated from an obstacle [19],[20]. The research center for the DPR RI Expertise Agency explained that there are still obstacles in the application of online learning such as the lack of human resource capabilities in managing existing technology (both educators and students), lack of clarity in local government directives regarding the learning system being implemented, curriculum adjustments to learning needs, and limited facilities and infrastructure, especially technology support and internet networks. Many complaints were raised by the public regarding the implementation of online learning, such as limited technology facilities and limited internet networks in some areas [21]. Reporting from national.kompas.com, the Indonesian Child 
Protection Commission (KPAI) received at least 246 student complaints complaining about online learning. KPAI commissioner RetnoListyarti said complaints related to internet quota were recorded at the highest, namely $43 \%$ of the number of complaints received.

The existence of online learning requires teachers to be open to technology [22]. Based on research data obtained by researchers, the application of learning carried out by teachers online as an alternative to learning in the face of the Covid-19 pandemic in economic subjects in high school has an effect on teacher performance, for young teachers. under 40 years of age there are no obstacles when learning is carried out online, but for teachers whose technological skills are lacking due to a lack of updates (not updating) and teachers over 40 years of age find it difficult to do online learning. Therefore, training is needed that can help teachers in online learning.

The implementation of online learning requires a fairly high cost for providing internet quota, procurement of standard smartphones for online use, a strong internet signal network, and not to mention if there are questions that make it difficult for students. Based on the explanation from the teacher, it is stated that online learning is an opportunity for stubborn students not to take part in learning and not to submit assignments for various supporting reasons [23]. Of course, the problems that teachers and students complain about have a big impact on the effectiveness of the application of online learning. Therefore, a solution is needed that must be applied by educators and students to anticipate various obstacles that can occur.

\subsection{Alternative learning solutions in the face of the Covid-19 pandemic in economics in high school}

The implementation of online learning does not necessarily run smoothly, based on research data that has been conducted by researchers, it is known that the application of online learning actually creates new problems for teachers and students. Therefore, there must be a solution that can be used by teachers in dealing with various kinds of problems that arise from ongoing online learning.

The rise of the Covid-19 pandemic case has made many schools still have to implement online-based learning. Many schools provide policies for teachers to use online learning platforms that are easily accessible to teachers and students, such as google classrooms, google meet, zoom.us, and short message applications such as whatsapp.

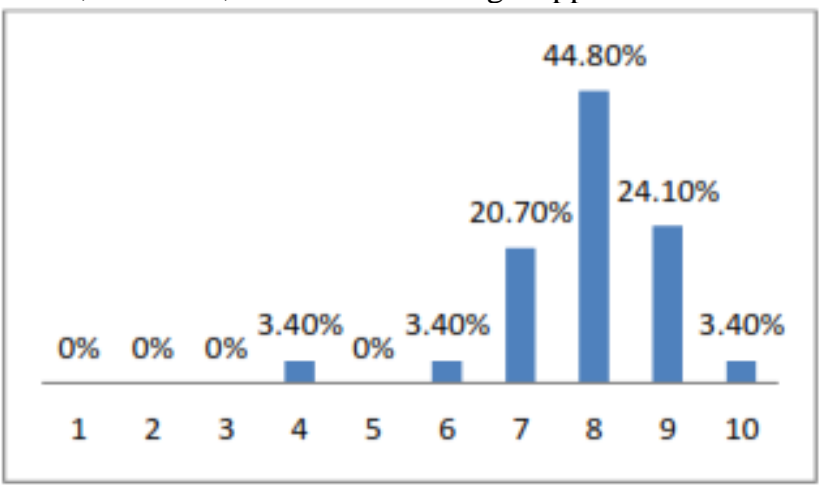

Fig. 5 The value given by teacher relates to the ease of access to use of learning facilities

Based on research data, it is known that an average of $44.8 \%$ of teachers gave a score of 8 for online learning platforms, $24.1 \%$ gave a value of 9 , and $3.4 \%$ gave a value of 10 which 
means online learning. using an online learning platform. actually easily accessible to students and teachers. Because online learning platforms help teachers and students to be able to carry out the learning process anywhere and anytime [24]. Teachers can be more innovative if they use an online learning platform because teachers can modify their learning to be more innovative by using the learning facilities available on the platform, so that students are more motivated and learning objectives can be achieved [25].

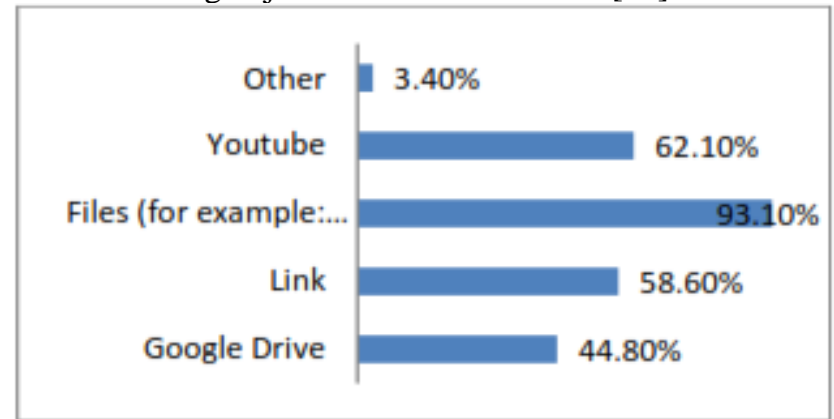

Fig. 6 Learning facilities use in delivering course material online learning

The development of e-learning is needed to improve the quality of learning [26]. The availability of learning facilities can improve the development of online learning [7]. The facilities provided by online learning platforms are quite diverse, for example the facilities for entering learning materials in the form of power) point, youtube link, google form, google doc, and many more. Regarding this, there were $93.1 \%$ responses which explained that generally teachers delivered subject matter in the form of files such as words, power points, and even learning videos. $62.1 \%$ of teachers delivered learning materials using YouTube, $58.6 \%$ of responses delivered subject matter using links for students to access. And there were $44.8 \%$ of responses using Google Drive, and there were $3.4 \%$ of responses that stated they preferred the Google form to deliver learning materials The application of these technologies helps teachers improve skills technology so that it becomes more updated and more aware of technological developments.

In the implementation process, the application of online learning cannot be separated from the obstacles that arise from students [12]. Based on the teacher's explanation, the tendency of students not to take part in learning for various reasons is very likely, such as no internet signal, damaged cellphones, illness, and so on. Therefore, teachers provide leeway for students in implementing online learning, teachers always remind students to take part in learning, schools provide quota packages to students through boss funds, and schools allow students to use ICT laboratories for students who need to carry out online learning. Actually, all kinds of solutions have been applied to overcome the various obstacles that exist, but if there are still stubborn students during the lesson, usually the homeroom teacher and counseling teacher will act decisively to remind them by notifying their parents or making home visits. to find out the student's condition.

\subsection{The effectiveness of the application of online learning as an alternative to learning during the Covid-19 pandemic in economics in high school}

The development of technology in the field of education has contributed significantly to improving students' learning abilities. The objectives of learning using technology can be achieved well by teachers by designing learning systematically so that learning is more 
effective and directed [27]. Teachers can use online learning platforms that are in accordance with student conditions to improve learning effectiveness.

The application of online learning using an online learning platform is one of the learning alternatives applied to anticipate the spread of the Covid-19 pandemic as an implementation of learning and working at home policies [28]. Based on research data, the teacher explained that the application of online learning using an online learning platform was known to be quite effective in helping teachers in distance learning. Online learning is a challenge in itself for teachers, because teachers are required to be more creative and innovative in providing learning material so that students can learn independently and students do not get bored easily [29]. Even though in fact the application of online learning also makes it difficult for teachers because teachers get tired easily when making learning materials and when correcting student assignments.

When viewed from the perspective of its effectiveness, the application of online learning by utilizing online learning platforms such as google classroom, google meet, zoom.us, and so on is indeed effective because there are many learning features that teachers can use in providing learning to students. can actually help teachers to provide material in more innovative ways [12]. But in reality, based on the teacher's explanation, face-to-face learning is much more efficient when learning takes place because the teacher can directly overcome student learning difficulties and also the teacher can find out the student's ability to accept learning. . The teacher's figure as a role model who loves, hones, and fosters students more than the application of distance learning which makes the teacher biased and not maximal in providing learning to students.

\section{Conclusion}

The Covid-19 pandemic has an impact on changing learning methods from face-to-face learning to online learning, learning activities that were initially carried out in school due to the pandemic must be carried out at home. This method of learning then makes many teachers use a variety of online learning media as an alternative to learning which actually causes many complaints from students such as the availability of internet networks, availability of quotas, or even the availability of facilities and infrastructure needed by students such as cellphones or laptops. However, related to the complaints felt by students, the school has actually provided a lot of ease of learning to students, such as internet quota packages, learning flexibility, and schools allowing students to use ICT labs for students who need to carry out online learning.

The implementation of online learning provides an interesting experience for teachers and students. The existence of this kind of learning, requires teachers to be more open to technology. Teachers are required to be more innovative and creative so that all forms of information conveyed can be easily understood by students. The teacher strives to provide learning flexibility to students so that students do not feel pressured when learning takes place, such as providing material that is easily understood by students, giving uncomplicated evaluation questions, and the teacher trying to understand the student's learning load so as not to be burdensome.

Online learning is implemented by teachers using learning platforms that can be easily accessed by students, such as google classrooms, zoom.us, google meet, and even mailing list media such as WhatsApp and email. This learning platform is a learning platform that has been chosen by many teachers for online learning. Because this learning platform provides various kinds of learning facilities that can be easily used by teachers to deliver 
learning materials more innovatively. Therefore, the application of online learning as an alternative to learning by utilizing online learning platforms has been proven to be effective during the Covid-19 pandemic in economic subjects in high school as a form of implementation of learning and working at home policies. Although basically the implementation of learning is more efficient during face-to-face learning, this is still difficult to implement due to the soaring cases of the Covid-19 pandemic.

\section{References}

[1] Cao, W., Fang., Z., Hou, G., Gan, M., Xu, X., Dong, J., \& Zheng, J. 2020. The Psychological Impact of the Covid-19 Epidemic on College Students in China. Psychiatry Research.

[2] Ali, W. 2020. Online and Remote Learning in Higher Education Institutes: A Necessity in light of COVID-19 Pandemic. Higher Education, 10(3).

[3] Crawford, J., Butler-Henderson, K., Rudolph, J., \&Glowatz, M. 2020. Covid-19: 20 Countries Higher Education Intra-Period Digital Pedagogy Responses. Journal of Applied Teaching and Learning (JALT). 3(1).

[4] Aunurrahman. 2013. Belajar dan Pembelajaran. Bandung: Alfabeta.

[5] Pujiati. 2007. Pengembangan Bahan Ajar PraktikumPengantarAkuntansi. Jurnal Ekonomi dan Pendidikan, 4 (2), 36-53.

[6] Indrajit, R. E. 2016. E-LEARNING DAN SISTEM INFORMASI PENDIDIKAN Modul Pembelajaran Berbasis Standar Kompetensi dan Kualifikasi Kerja Edisi 2. Yogyakarta: Preinexus.

[7] Singh, A., \& Singh, Lata B. 2017. E-Learning for Employability Skills: Students Perspective. Science Direct Procedia Computer Science, 122,400-406.

[8] Rochaety, E. dkk. 2005. Sistem Informasi Manajemen Pendidikan. Jakarta: BumiAksara.

[9] Firman \& Rahman, S. R. 2020. Pembelajaran Online di Tengah Pandemi Covid-19. Indonesian Journal of Educational Science (IJES)., 02(02), 81-89.

[10] Din, N., Haron S., Ahmad, H., Rashid, Rahmah Mohd. 2015. Technology Supported Cities and Effective Online Interaction for Learning. Procedia - Social and Behavioral Sciences, 170, 206-214.

[11] Rachmawati, Yuanita. 2020. Studi Eksplorasi Pembelajaran Pendidikan IPA saat Masa Pandemi Covid-19 di UIN Sunan Ampel Surabaya. Indonesian Journal of Science Learning. 1(1), 32-36.

[12] Patricia, A. 2020. Students Acceptance of Online Learning Due to Covid-19. International Journal of Educational Research Open.

[13] Sugiyono. 2016. Metode Penelitian Kuantitatif, Kualitatif, dan $R \& D$. Bandung: PT Alfabeta.

[14] Littlejhon, Allison and Pegler, Chris. 2007. Preparing for Blended E-Learning. New York: Routledge.

[15] Lage-Cal \& Folgueras-Diaz. 2020. Investigation of the Effectiveness of Online Learning Tools for Energy Performance Certificates Preparation. International Conference on Energy and Environment Research. 6, 609-614.

[16] Simuth, J., \& Schuller, I. S. 2014. Cognitive Style Variable in E-learning. Procedia - Social and Behavioral Sciences, 116,1464-1467.

[17] Tigowati, Efendi, A., \& Budiyanto, C. 2017. The Influence of the Use of E-Learning to Student Cognitive Performance and Motivation in Digital Simulation Course. Indonesian Journal of Informatics Education, 2(1), 41-48.

[18] Janse, Elsie Sophia van Rensburg. 2018. Effective Online Teaching and Learning Practices for Undergraduate he Sciences Students: An Integrative Review. International Journal of Africa Nursing Sciences. 9, 73-80.

[19] Frehywot, S., Vovides, Y., Talib, Z., Mikhail, N., Ross, H., Wohltjen, H., Bedada, S., Korhumel, K., Koumare, A. K., \& Scott, J. 2013. E-Learning in Medical Education in Resource Constrained Low and Middle-income Countries. Human for Health, 11(4), 1- 15.

[20] Minuti, A., Sorensen, K., Schwartz, R., King, W. S., Glassman, N. R., \&Harbousha, R. G. 2018. Librarians Flip for Students: Teaching searching Skills to Medical Students using a Flipped Classroom Approach. Medical Reference Services Quarterly, 37(2), 119-131. 
[21] Arifa, Fieka Nurul. 2020. Tantangan Pelaksanaan Kebijakan Belajar dari Rumah dalam Masa Darurat Covid-19. Info Singkat - Kajian Singkat terhadap Isu Aktual dan Strategis. XII (7), 13-18.

[22] Kemp, A., Palmer, E., \& Strelan, P. 2019. A Taxonomy of Factors Affecting Attitudes Towards Educational Technologies for use with Technology Acceptance Models. British Journal Education Technology. 50, 2394-2413.

[23] Albelbisi, N., \& Yusop, F. 2019. Factors Influencing Learners Self-Regulated Learning Skills in a Massive Open Online Course (MOOC) Environment. Turkish Online Journal of Distance Education. 20, 1-16.

[24] Misut, M., \&Pribilova, K. 2015. Measuring of Quality in the Context of E-Learning. ProcediaSocial and Behavioral Sciences. 177, 312-319.

[25] Harandi, S. R. 2015. Effects of E-Learning on Students Motivation. Procedia-Social and Behavioral Sciences. 181, 423-430.

[26] Brosser, L., \& Vrabie, C. The Quality Initiative of E-Learning in Germany (QEG) - Management for Quality and Standards in E-Learning. Procedia - Social and Behavioral Sciences. 186, 1146-1151.

[27] Zulfikar, Ahmad Fikri., Muhidin, Aeng., Pranoto, dkk. 2019. The Effectiveness of Online Learning with Facilitation Method. Science Direct Procedia Computer Science. 161, 32-40.

[28] Hodges, C., Moore, S., Lockee, B., Trust, T., \& Bond, A. 2020. The difference between emergency remote teaching and online learning. EDUCAUSE Review. https://er. educause.edu/articles/2020/3/the-difference-between-emergency-remote-teachingand onlinelearning.

[29] Supiandi, M. I., \& Lisa, Y. 2018. The Utilization of Information and Communication Technology (ICT) on Learning in the 21st Century. International Journal of Academic Research and Development. 2(3), 869-875. 